\title{
Reflexive resilience and community supported agriculture: The case that emerged from a place
}

\author{
Oliver Moore, ${ }^{a *}$ Olive McCarthy, ${ }^{\mathrm{b}}$ Noreen Byrne, ${ }^{\mathrm{c}}$ and Michael Ward ${ }^{\mathrm{d}}$ \\ Centre for Co-operative Studies, University College Cork
}

Submitted August 6, 2013 / Revised December 19, 2013, February 24, March 2, and March 14, 2014 / Accepted March 14, 2014 / Published online June 4, 2014 / Correction made to sixth paragraph of the Introduction on page 138 to correct two farm names, March 9, 2015

Citation: Moore, O., McCarthy, O., Byrne, N., \& Ward, M. (2014). Reflexive resilience and community supported agriculture: The case that emerged from a place. Journal of Agriculture, Food Systems, and Community Development, 4(3), 137-153. http://dx.doi.org/10.5304/jafscd.2014.043.007

Copyright (C) 2014 by New Leaf Associates, Inc.

\begin{abstract}
While some aspects of what has broadly been called alternative agri-food networks (AAFNs) are relatively prominent in Ireland, including farmers' markets, garden plots (or allotments), and the GIY, or the Grow it Yourself home gardening phenomenon, community supported agriculture (CSA) initiatives are still rare in Ireland. One of the few, earliest, and most prominent CSAs in Ireland is the subject matter of this article. This paper first contextualizes the study with some of the relevant literature on AAFNs, including a 'civic turn' in the European literature on AAFNs, toward civic food networks (Renting, Schermer, \& Rossi, 2012). Key developments in this literature,

\footnotetext{
a * Corresponding author: Dr. Oliver Moore, Centre for Cooperative Studies, O’Rahilly Building, University College Cork, Western Road, Cork, Ireland; 00353868047854 ; olivermooreresearch@gmail.com

b o.mccarthy@ucc.ie

c n.byrne@ucc.ie

d $\underline{\text { michael.ward@ucc.ie }}$
}

including equity, governance, place, and empowerment, are unpacked and demarked as especially important. The studied CSA's organizational restructuring in the face of productivity pressures is examined in detail. While CSAs specifically involve sharing risks and rewards, and while this is described as an acceptable uncertainty, when pushed to its limits the actualized risk of not enough produce became in fact unacceptable for this CSA initiative. The process through which this member-owned and -operated CSA critically self-assessed and restructured in the face of challenges is a core part of what is termed here as a 'reflexive resilience.' The implications of reflexive resilience are then analyzed to draw out research implications. 'Reflexive' refers here to being critically self-aware and willing to change, and then changing. 'Resilience' refers to being prepared for shocks and responding accordingly to said shocks if and when they occur. Taken together, the term 'reflexive resilience' describes a CSA's adaptive awareness.

That this reflexive resilience emerged in a member-owned and -operated CSA may make this 
CSA more a model for communities to use, if the aim is to have a truly civic agriculture (Lyson, 2000) as part of a more civic rural space. Implications for more fruitful interactions between research and practice are also suggested.

\section{Keywords}

alternative agri-food networks, civic agriculture, community supported agriculture, CSA, reflexive resilience

\section{Introduction}

Ireland has had a strong tradition in export-led farming and food for hundreds of years (Crotty, 1965; Tovey, 1982, 2001). Even into the late $20^{\text {th }}$ century, one-third of net foreign earnings were coming from agri-food, while export-led growth plans for beef and especially dairy have re-emerged strongly since the economic near-collapse of 2007/2008 (Department of Agriculture, Fisheries and Food, 2010).

Concurrently with these processes, since the 1970s and the migrant-led organic movement (Moore 2006b; Tovey 1997, 2002) Ireland has had a small but persistent cohort engaged in what would come to be described as the alternative agrifood networks. In the mid- to late 1990s, this dynamic began to become especially prominent through the farmers' market phenomenon, which emerged and spread rapidly (Briscoe, McCarthy, Moroney, O'Shaughnessy, \& Ward, 2010; Moore, 2006a, 2006b, 2006c, 2008).

Curiously, there are very few CSAs in Ireland.

Two consumer groups have approached farmers in the southwest county of Cork to create an oats and potato CSA channel of supply in recent years, while a producer-led seasonal vegetable CSA exists in Cork. Two consumer groups have a CSA arrangement with growers north of the capital city, Dublin, and west of it in Kildare. Beyond that, sporadic single-crop or product arrangements happen below the radar from time to time.

Reasons for so few CSAs have been speculated as including the relative strength of other aspects of the AAFNs, especially farmers' markets, and a desire by all parties to avoid displacement; the prominence of allotmenteering and the home gardening movement called GIY (Grow it Your- self); the recession, in which Ireland suffered significantly from the resulting austerity, with a decline in discretionary spending on organic food (Bord Bia, 2013). It is also the case that the supply of fresh fruit and vegetables is relatively low at the Irish latitude over the winter months, being as it is in northwest of Europe, and thus the momentum may be lost somewhat in efforts to maintain CSA connectivity over 12 months.

But what is a CSA? CSAs are a particular type of food production-consumption network. CSAs involve, to varying extents, sharing the risks, responsibilities, and rewards of production (DeLind, 1999; Saltmarsh, Meldrum, \& Longhurst, 2011; Soil Association, 2010). Simply put, this means that if the harvest is good, there is more produce for members; if it is poor, there is less. More broadly, it means that all going well and to members' wishes, the harvest will be good - to think, to eat, and for the future. However, if there are production disasters, no produce or compromised produce will be available, irrespective of the fact that payments are made in advance by consumers/members. This level of shared commitment specifically sets CSAs apart from other aspects of what has been described, and will be described later, as alternative agri-food networks (Lamine, 2005).

These shared-risk-and-reward food production systems first emerged as Teikei in Japan in 1965, but were also pioneered by anthroposophy-inspired practitioners in the 1950s and 1960s in Germany, first at Buschberghof farm. Pioneers from Buschberghof and Swiss CSAs established the first of their kind in the U.S. at Temple-Wilton Community Farm (Temple, New Hampshire) and Indian Line Farm (South Egremont, Massachusetts) in 1986 and 1984, respectively. Other European countries developed CSAs in the 1990s, while the movement especially flourished in the U.S. (Soil Association, 2010).

In all forms of CSA initiatives, significant compromises and adjustments are made to the realities at the other end" of the food system; producers adjust to consumers' expectations, while also imparting information on the realities at their end, and vice versa, again to varying levels.

In the complexity of thousands of CSAs glo- 
bally, not all will fit into a neat typology. Nevertheless, Ravenscroft and Taylor (2009) describe six styles in a matrix of CSA forms. These are needsbased share farming; rights-based share farming; seasonal direct marketing; multifarm CSAs; community buying groups; and community-owned social enterprises. The third, fourth and sixth of these are producer-led, while the rest are consumer-led. The first two require further explanation due to the use of the political terms "needs" and "rights": needs-based involve producers and consumers contributing what they can and taking what they need; rights-based involve equal contributions and shares from and to members.

In this paper we explore one of the few CSA initiatives in Ireland, and the only member-owned and -operated one. We suggest that the CSA has important things to say about civic participation, when examined through the lenses of empowerment, equity, place, and governance. We first contextualize the study with some of the relevant literature on AAFNs, and the later literature on civic food networks. Key conceptual developments in the literature, namely equity, governance, place, and empowerment, are chosen as being especially relevant for this study. We then justify and explain the ethnographic methodology used and describe a year lived in and through the life of the CSA. Next, we analyze the CSA's organizational restructuring in the face of some food-production uncertainties. These uncertainties were acceptable to some CSA members and unacceptable to others (DubuissonQuellier \& Lamine, 2008), Limits on vegetable availability is an example of an acceptable uncertainty, while use of agri-industrial inputs and processes is an example of an unacceptable uncertainty. However, the balance between acceptability levels played out in a specific way in this CSA, when vegetable production was perceived to be especially constrained. We posit reflexive resilience - the process through which this member-owned and -operated CSA was ready and also able to critically self-assess and restructure in the face of challenges - as a way to explain how this CSA functions. These two words are similar but have subtle differences. 'Reflexive' refers here to being critically self-aware and willing to change, and then changing. 'Resilience' refers to being prepared for shocks and responding accordingly to said shocks if and when they occur. Taken together, the term reflexive resilience describes a CSA's adaptive awareness.

The process through which reflexive resilience expressed itself is important. We argue that the fact that this CSA is member-owned and-operated is core to its reflexive resilience, and that this may make it more a model for communities to learn from, if the aim is to move toward civic agriculture (Lyson, 2000) as part of a more civic rural space. We also explore implications for more fruitful interactions between research and practice related to CSAs.

\section{Literature: What's on the Alternative Food Table?}

The literature on AAFNs has tried to examine how, in food provisioning systems, the noneconomic gets to be valued, in various senses. Notions of quality, regard, embeddedness, reflexivity, and all with relational components, have been suggested in some of the prominent literature that initially tackled this area (for example Murdoch, Marsden, \& Banks, 2000; Murdoch \& Miele, 2004; and Sage, 2003). Direct sales of various forms, such as farmers' markets and box schemes (i.e., prepaid seasonal deliveries without the CSA risk-reward dimension), have been the subject matter, while the emphasis has been on social and/or environmental factors related to these methods of distribution. AAFNs involve close (empathetic and geographical) connections between producers and consumers, who act in what they feel is a more environmentally benign and socio-culturally embedded manner. These and other studies tried to explain the process through which local, artisan, organic foods, produced in ways that show, in some sense, respect for the environment and connectivity with the region, are produced, distributed, and consumed.

While the scale and importance of AAFNs has been the subject of debate (Goodman, 2004; Van Der Ploeg \& Renting, 2004), there have been other considerations too. Even within specific areas of AAFNs, the farmers' market context as an example, various economic and other pressures can be found. Kirwan (2004) points to pressures relating 
to distance and disconnection: that is, the people, products and place all losing connectivity, or integrity, when faced with the need for commercial viability. Viability is expressed through the array of produce on display, from the producer, locality, region, nation, and globe.

Defining AAFNs as 'alternative' is problematic for some: for them, instead, understanding the specificities of different examples of food production-consumption systems is key. Smith \& Marsden (2004) point to specific sectoral dynamics in differing distributional systems in building a case for certified organic foods. Holloway, Kneafsey, Venn, Cox, Dowler, \& Tuomainen (2007) point to limits in the literature's methodological scope, suggesting a need for understanding heuristic fields such as site of production, production methods, supply chain arena of exchange, producerconsumer interaction, motivation for participation, and constitution of individual and group identities. Applying this more geographic analysis allows for an examination of "how the specific ordering and spatiality of particular projects can effectively challenge centers of power in the food supply chain" (Holloway et al., 2007, p. 15).

In the field, new producer-consumer dynamics emerged in Europe in the 2000s. Likewise, in North America an interest in local food and the CSA phenomenon grew rapidly. Authors thus have advanced the literature on AAFNs, introducing concepts such as local food systems (e.g. Balázs, 2012; Karner, 2010), or short food supply chains (Marsden, 2000). Flora and Bregendahl (2012), while retaining CSA conceptually within the AAFN domain, point to how collaborative CSAs (multifarm CSAs, number four in Ravenscroft and Taylor's typology), which evolve to maximize multiple capitals (natural, cultural, human, social, political, financial, and built stocks and flows of assets)for individual producers and consumers, are more likely to endure. Thompson and CoskunerBalli (2007) describe CSAs' pragmatic inconveniences and choice restrictions as enchanting moral virtues. While much has been written on AFFNs and CSAs, for the purposes of this study, empowerment, place, equity, and governance have emerged as four newer and more promising elements, with 'civic' also an overarching consideration.

DeLind (1999, 2002, 2011), following Lyson (2000), has pointed toward 'civic agriculture' (2002), whereby local food systems can help develop an alternative commerce. Not only that, they can also promote citizenship and environmentalism within both rural and urban settings, through economic relations and, importantly, through common ties to, and physical engagement with, place.

However, DeLind (2011) also suggests that a genuinely place-based experience is absent from how the much valorized local food movement(s) function(s). This then denies deeper concerns about equity, citizenship, place-building, and sustainability. For DeLind, the ownership and practice of the notion of local food can alienate many local people, people whose genuine cultural expressions of identity are excluded from the sometimes rarefied discourse on local food. These expressions might not fit into the hegemonic clichés of good food, but they are genuine placebased expressions, which need to be integrated into a regenerative agri-food system.

DeLind (2011), following Dahlberg (1993), moves the analysis of local food away from the instrumental and toward the contextual, while integrating the 3Es of sustainability: ecology, ethics, and, importantly for her, equity or fairness in the distribution of voice, resources, and power. The latter allows for a public culture of democracy expressed through participation in problem solving locally, protecting the commons, recognizing the virtue of necessity (Vitek, 1996), assuming and sharing public responsibility, and empowering community residents and sets of interconnected communities. Better understanding of and working on genuine community needs, while also using a farmers' market to train and upskill local residents, are cited as examples of the real work of creating participatory local food systems. This then is also "the cultivation of a civic we-ness" which ultimately should "give the local food system definition and holding power" (DeLind, 2011, p. 279).

Unsatisfied with the conceptual limits of AAFNs for describing changes in Europe, Renting et al. (2012) map both the terrain and the state of the research on what they term "civic food net- 
works." This more consumer-driven, or certainly, consumer-participatory terrain is wide and involves governance structures that emphasize civil society. This terrain is fragmented, often underestimated, and partially 'under the radar,' as groups often operate in an unregistered way. Some of the components of this terrain are food co-ops and collective purchasing groups; CSAs; (possibly) box schemes; garden plots, community gardens, and Grow Your Own initiatives; 'adoption' of production resources (e.g., cow, tree, chicken, land); participation in food-oriented community organizations; local food movements; and food policy councils.

There are other considerations, too: the relations with and role of producers in these new networks is still largely unclear, as are policy or support measures. Various factors that may inhibit the development, heterogeneity or (non)occurrence of these networks include farm structure (scale, type of production); tradition of gardening and/or home production; availability of local/organic food in conventional channels; level of buying power of consumers; existence of food culture and/or sociopolitical awareness on food issues; occurrence of 'shock' by food scandals; degree in which conventional farming or retail have taken up multifunctionality to meet new societal demands. Importantly, the growth model is based on multiplication instead of scale enlargement. It can be suggested that this, in itself, is a civic, 'open source' growth, or more specifically, proliferation, model (Renting et al., 2012).

According to Dubuisson-Quellier and Lamine (2008), France and Italy have seen the fast and quite widespread emergence of two distinct forms of civic food networks that merit consideration and analysis. These are consumer purchasing groups, Gruppi di Acquisto Solidale (GAS) in Italy, and Association pour le Maintien de l'Agriculture Paysanne (AMAP) in France. Both these civic food networks are mostly consumer-driven, falling into type five on Ravenscroftand Taylor's (2009) typology as community-buying groups, although they vary in style and substance. Some have even purchased farmland for strategic and political reasons.

In this new aspect of civic food networks, in describing GAS both Brunori, Rossi, and
Malandrin (2010) and Fonte, Pinto, Eboli, Ornella, and Salvioni (2011) find, like DeLind (2011), that equity is a key new consideration, one "which may have a far more radical impact on the structures of daily life"(Brunori et al., 2010, p. 48). Because of this, they continue, "GAS are a peculiar type of AAFN, aimed at fulfilling the demand for fresh, local, sustainable and nutritious food for middle to low income consumers. Rather than looking at typical, locality [sic], and excellent quality food, GAS focus on daily food" (p. 48). This contrasts with the "jewel-shop" status of health food stores that serve mainly more middle-class consumers as referenced in Fonte et al., 2011).

Moreover, as Renting et al. (2012) also point out, these authors also suggest that new consumerengaged movements represent an innovative type of governance. GAS enroll stakeholders, who can be involved in an organizational capacity, including organic certification bodies, local councils, churches, academics, and trade unions. According to Brunori et al. (2010), in the GAS, new thinking about food can emerge and be legitimized, and new economic patterns and adaptive rules can be expressed. Relationships are defined more by shared values than competition, although this is a constantly evolving and negotiated process. With these new arrangements, farmers and consumers learn to adapt to each others' values, desires, and preferences: farmers may grow their businesses in a specific style with these customers in mind, or they may change some of their practices but expect changes from the consumers, too (Brunori et al., 2010).

New governance structures are also important in the Cardona and Lamine (2011) study of collective action and an AMAP. They describe how an AMAP has been the significant driver in developing multi-stakeholder groups that have buffered part of the south Paris region against certain encroachments, including land acquisitions for military or road-building purposes. In the local municipality, the AMAP was able to provide for an improvement in canteen food quality, in line with government policy on healthy food. Importantly for our analysis here, this sort of civic behavior also alters the place in which the AMAP functions. By being a participant in regional politics, collective 
power, and governance, the authors consider ecological modernization through rural development and transitioning is in operation (Cardona \& Lamine, 2011).

Dubuisson-Quellier and Lamine (2008) examine the engagement and empowerment levels of consumers in French AAFNs, including AMAPs. This involves studying the balance between delegation and empowerment, as well as between acceptable and unacceptable uncertainties. The authors study how consumers are enrolled in a network by a process of translation that establishes modes of ordering between actors (producers, consumers, retailers, importers, processors, etc.) and intermediaries (standards, logos, advertisements, distributional spaces, texts, etc.). Marketplace mechanisms can allow consumers to delegate toward intermediaries, to express an aggregated individualized collective action, or be politically empowered players in a collectively constructed food system. The latter can involve the framing and governance of collective choices by consumers as political actors.

Civically engaged and collectively acting, these empowered groups can temper the governance structures of their locales to at least some extent. These consumers can pressure local authorities to organize for particular types of school meals, farmers' markets, or for other value-laden food options. For the AMAP, empowered collective action can involve using skills to help it function through volunteering with weeding, accountancy, public relations, or other areas. Working out what are acceptable and unacceptable uncertainties much like Thompson and Coskuner-Balli's (2007) enchanting pragmatic inconveniences and choice restrictions - is key. So for example seasonally constrained choice of specific vegetables (acceptable), is traded off against unacceptable uncertainties, such as the possible long-term effects of agriindustrial inputs or processes (e.g., genetic modification, herbicides). Consumers still negotiate and balance delegation and empowerment, though they may also change their food-related trajectories over time. This trajectory change may involve becoming more embedded and also empowered in their food choices. By engaging with other stakeholders in their communities, empowered consumers are involved in the process of governance.

These new civic food networks in Europe, then, point to significant enrollment of considerations of place, equity, empowerment, and governance. Taken with DeLind's (2011) place-based emphasis on equity, it is clear that Renting et al. (2012), and previously Smith and Marsden (2004) and Holloway et al.(2007), are correct in seeing conceptual and explanatory limits to the notion of AAFNs.

\section{Methodology}

For the purposes of this research, the lead researcher became an active member of the CSA being studied. In rural ethnographic research, a traditional worry has been the loss of objectivity in 'going native.' More recently, however, the level of access more embedded ethnographers can have has emerged as a useful methodological approach. For Heley (2011), participant observation, nativism, and especially being local can provide this exceptional access to rich quality data. Backyard ethnographies - researching potentially even intimately familiar study worlds - can engender acceptance of the researcher while also generating what are insider, privileged observation points (Heley, 2011).

The positionality of the self-reflexive researching subject (Fuller, 1999) is key to the successful implementation of this approach. This involves consciously working on both geographic and cultural distance; being fully aware of the vital inevitability of closeness rather than detachment as inherent in ethnographically understanding a culture; all the while being critically self-aware, in an ongoing fashion, of engaging in the practice of research. Indeed, and aptly, DeLind's (1999) anthropological study of a CSA specifically makes the case for the "more complete knowledge and a more organic existence, individually, collectively, sensually, and intellectually" (p. 4), which emerges from her recognizing her academic activism and grassroots engagement, while revealing "less than perfect" experiences in the real life of the CSA.

Ethnographic studies present challenges for researchers in terms of identifying people and places to study; gaining access to those people and places; establishing the trust of those being studied; and exiting the field (Heley, 2011). With a mem- 
bership-based CSA, identification was straightforward. In terms of access and trust, the lead researcher was already well-known to many CSA members, having been a member of, though not resident in, the nearby intentional community since 2007. The latter was central to the establishment of the CSA, as will be seen later. Exiting occurred through circumstances not related to the research, although relations were retained via the ongoing intentional community link.

The level to which the lead author participated and was immersed in the life and functioning of the CSA was typical of an especially active member. For a 12-month summer-to-summer period (2010 to 2011), the lead author moved to the town where the CSA is based. He became an active paying member, primarily collecting and adapting to fully using during mealtimes what produce the CSA provided. It also involved visiting the production fields regularly, organizing and participating in fund- and awareness-raising events, and other volunteering. Events were held on the land and in the locale, including in church halls.

A central part of being a member was visiting the distribution center and collecting produce. This was done between two and five times each week. There the researcher met and spoke with other members, encountered the building itself and the produce, in all its colors, shapes, sizes, availability levels, and styles. He also participated in a members' survey, conducted through interview. Community meals were held most Fridays, and while these were largely made up of CSA members, others were also present. After five months, he became a board member of the CSA, and also a member of the subcommittee on education, events, communication, and fundraising. This then gave him significant access to people, data and decisionmaking in the CSA, including on membership, finance, and planning. This included the members' survey information, which was part of the build-up to an extraordinary general meeting (EGM). A newsletter and column in an organic farming magazine were coordinated by the subcommittee.

Events for CSA members were organized, including farm walks, cookery demonstrations, and other social gatherings. As well as regular meetings (once per month for the board, five times for the subcommittee), digital communications telephone, photographic and email - were part of the lived experience of being a member of this CSA. In this period, approximately 160 CSArelated email communications took place, some with numerous conversations from the original email. Dozens of CSA-related photographs were taken, while hundreds more were available.

For this year, regular and detailed CSA-specific notes were written up by the lead researcher on experiences as they happened. These included experiences of collection, 'processing,' preparing, and eating, along with notes on key moments and events that occurred. CSA-related encounters with others (at the distribution point, at events, and elsewhere) were likewise written up. These were filed with relevant photos and digital communications, and then coded and where necessary recoded as per the emergent themes of equity, empowerment, place, and governance.

\section{Findings: The Practical Experience of a Year Lived in the Life of a Community Farm} The CSA studied has been in operation since 2008. The CSA grew from an intentional community (also known as an ecovillage) established in the same small rural midlands town of about 500 people. Unusual for an intentional community, this one is essentially an appendage of the main town, rather than isolated from it. The intentional community began in 2004, with houses construction beginning around 2008, although it had been in planning since at least 1999. Most residents are from or were based outside of the locality. A large number, over 50 percent, are from Dublin. The town itself has an unusual heritage (by the standards of the Republic of Ireland), having three churches and a large Anglican/Church of Ireland and Methodist population. Though both the CSA and the ecovillage have separate legal identities, they are seen primarily as part of the same overall eco-newcomer tendency in the locality. Threequarters of CSA members were intentional community members in the early part of the research, while part of the farm's land is leased from the intentional community.

The biodynamic farming movement has been central to the establishment of CSAs in Europe 
and the U.S. (Soil Association, 2010). As some members and those affiliated with the intentional community had an interest in biodynamic farming, they were thus familiar with the concept. The intentional community also has an interest in selfsufficiency — its motto is "building sustainable community" - so owning the means of production of food would be typical of its approach.

To establish the CSA, loan stock was generated from about 40 people in, affiliated with, or living in the small town because of the intentional community. From this loan stock, an 80,000 Euro loan from a German ethical bank was generated and people were repaid, although they remain as guarantors of the loan.

CSA membership is open to all in the locale, whereas membership in the intentional community involves living on the ecovillage site or having some intention of living on the site. The latter is usually defined by some sort of monetary commitment, either deposit, site, or ownership of a housing unit. After extensive outreach, CSA memberships started to emerge from the nearest large town, further diluting the ecovillage element of the CSA. Two-thirds of the approximately 50 family memberships are from the intentional community, with the remainder coming from the wider community.

The CSA is very much a membership-driven initiative. As will be explained in the following sections, using Ravenscroft and Taylor's (2009) six forms of CSA, this CSA operates a blend of type one and two - needs-and equity-based share farming - as well as type five, community buyer groups, as it is member-driven, not farmer-driven. Members own and operate the CSA, acquiring land on long-term leases and providing (contracting) the producers from within the membership. All producers and board members are CSA members.

Two separate holdings are farmed: an upper farm of 26 acres (11 ha) and a lower farm of 12 acres ( $5 \mathrm{ha}$ ). The upper farm consists of grains, field-scale vegetable crops, and livestock. Livestock regularly includes sheep and cattle and may include small numbers of goats, pigs, and hens. There is an emphasis on heritage breeds or varieties, including Kerry cows (a milking breed) for providing raw (i.e., unpasteurized and unhomogenized) milk. On the lower farm, 6 acres (2 ha) of vegetables are grown on the 12 -acre site. The farm is run to biodynamic principles and is a prominent participant of the biodynamic movement, though it is not a certified organic or biodynamic farm. ${ }^{1}$ There is an educational focus built into the memos and articles of the CSA.

In the year of research on which this paper is based (summer 2010 to summer 2011), membership rose from 47 family or individual memberships to 57 . Membership from outside the intentional community grew at a faster rate over the year. Standard family membership costs 20 Euro per week, but membership for the unwaged or retired costs 10 Euro. Single people paid less, with the unwaged or retired paying a proportion less again. This entitled members to 3 or more visits to the distribution point per week, to collect whatever level of vegetables and raw milk they felt they needed. This CSA was year-round, not seasonal, and did not operate a box scheme system whereby members receive a set amount of food. Instead, produce was delivered to a distribution point, from which members took what they themselves felt was a fair share, based on their own needs. There was no limit on the amount people could take; indeed there was no lock on the door, despite the fact that the distribution point was in the center of the main village. In practice, some members treated the distribution point as something of a larder, especially with raw milk available seven days per week. Meat was somewhat contentious among vegetarian members, who were, from their perspective, being asked to fund the preference of meat-eaters. During the research period, after membership consultation, meat became a "meat share," available to purchase separately from the regular supply of vegetables and milk.

The CSA's structure in the first half of the research period involved one full-time farm manager doing most of the work in the areas of livestock, dairy, grains, vegetables, poultry, education, and distribution. This farm manager

\footnotetext{
${ }^{1}$ Biodynamic farming is a version of organic farming but with cosmological and homeopathic-like dimensions, in tandem with more of a focus on closed production cycles. See http://www.biodynamic.org.uk/start-here/gardening.html
} 
interacted with the board of directors, while an advisory panel interacted with both the manager and the board. The board set the budget, based on member fees and on potential fund-raising estimates.

During the first summer of the research period, the lead researcher started to visit the farm and volunteer. A strong emphasis on joining in was immediately observed. Time was taken for children to be integrated into whatever work was being done, especially on days set aside for children's activities. There was a strong media and social media presence for the farm and its activities. Occasional members' meetings and food-oriented outreach events were held, including a high-profile TV event featuring a celebrity chef. Regular community meals were held most Fridays. In the previous years, these were events by and for the intentional community. Over the years the focus broadened to include the wider community, including CSA members. CSA produce tended to feature heavily at these events.

An example of an internal event was entitled "Raw: A milk party." This included information and demonstrations on uses for surplus milk (gluts often occur due to production changes; in the case of milk, this occurs with cycles of calving). The membership had something of a responsibility to deal with the surplus. The event also featured discussion on health and safety issues, milk-based or other dishes, and entertainment. Outreach-oriented events at local festivals and public events featuring well known chefs were also held. All these events involved the opportunity to make food for others to eat from the farm's produce. Other opportunities include contributing to the newsletter, from printing to writing to photographs and distribution. Direct production-related volunteering occurred too, in harvesting and planting.

Many members had their own allotment and membership in a whole-food wholesale buyers' group as well as CSA membership. A strong desire to shop locally rather than in large retailers in the regional towns was also expressed in conversations over the research year. The buyers' group provided wholesale deliveries of whole-food, primarily "nonfresh" (i.e., dried, canned, jarred, processed, etc.) produce, including nuts, seeds, pasta, flour, sauces, spices, coffee, and so on. This comprised mainly certified organic and, where applicable, fair trade, foods. A bread club was also in operation. This involved a baker who was also a CSA and intentional community member supplying pre-ordered organic, sourdough breads weekly.

Members also volunteered at harvesting and planting times, although some of the impetus for this has been transferred over to WWOOFers (volunteers through Willing Workers On Organic Farms). WWOOFers are volunteers on organic farms who for the equivalent of half a week's work receive bed and board. This was an especially sought-after place to WWOOF because of the intentional community and CSA combination; the costs and use of the WWOOFers are shared.

Accommodation for WWOOFers was to a high standard, in a newly constructed hostel, and the social side of things was more present than in some WWOOF host farms, which can by their nature be isolated. Members volunteer to feed WWOOFers. Members rotated the task of feeding WWOOFers twice a day with an early afternoon and early evening meal. Depending upon WWOOFer preference, these meals could be served in the cook's home or delivered to the hostel.

Members were very much at the core of the CSA's operations. All involved in the functioning of CSA were members, including the coordinators (i.e., the growers and farmers). Members also had the opportunity to make formal and informal suggestions related to the food, including milk, distribution, and crop planting plans. The latter was done specifically through a yearly survey. Members also volunteered at events, both internal and outreach.

\section{Restructuring}

Members were very supportive of the concept of the CSA, but also frustrated at the lack of produce at times. This was especially the case for members who also had garden plots on the intentional community land. A reason posited for reduced produce was a severe winter frost. Yet those with garden plots experienced the same frost and still claimed to have relatively good harvests. In the first half of the research year, communication between the 
board and the membership, and a lack of farm grown vegetables, were membership concerns. Some members expressed concerns over the producer's judgment and performance. There were some unavoidable causal factors for the relative shortage of vegetables, including the especially tough winter frost and an unexpected bereavement of a very close family member of the sole contracted producer. Indeed, certified organic vegetables were bought in over the winter to compensate for the lack of vegetables. To fill the gap in produce, there was a combination of buying-in regional certified organic produce and receiving biodynamic vegetables in lieu of future productivity, the latter being a long-term barter given on trust.

Over the course of the research year, the CSA was restructured to deal with what were perceived by members to be flaws in the structure. In particular the structure, it was thought, placed too broad a work load on the farm manager and discouraged connectivity between members, volunteers, and the farm's management. This restructuring was part of a process that involved a one-time members' survey carried out through direct visits from board members to members' houses, where the above concerns were expressed and recorded.

These pressures and problems were serious enough to lead to an extraordinary general meeting (EGM). The CSA was in debt and struggling financially, a situation that improved somewhat over the course of the study year. This EGM was fraught but did lead to a change in structure. The process used at the EGM included a 'conversation café': members sat around tables, and each table suggested a set number of issues of importance. Color-coded stickers were placed beside the issues to denote relative importance of the issue. What emerged chimed with the members' survey, with lack of produce the key concern.

The new structure involved more members doing more activities and having a greater role in the functioning of the CSA. Instead of a full-time farm manager/producer, three part-time coordinators (i.e., farming and growing memberproducers) became the main producers. Only two of these new coordinators were paid from the CSA's coffers; the third one was on a government- funded back-to-work type of scheme. Each had his or her own area of specialization. A new coordination team was established and the existing advisory group was reinvigorated to aid the coordinators. The coordination team met weekly or fortnightly and included board members and the core coordinators. It reported to the board on the day-to-day functioning of the farm and any matters that arose. The farm advisory group was strengthened to include a wider and more diverse range of experts. These included experts in each of the seven activity areas: vegetables, poultry, livestock, dairy, grains, distribution, and education. Some advisors were also experts in organic or biodynamic methods for the activity. Others on the advisory group were local farmers, community members, and business people, which helped with outreach.

There was also an activities support group, or more specifically, a system to facilitate activities' supports. So, for example, an education, events, communication, and fundraising sub-committee was formed; groups were also formed to deal with other matters that arose, such as raw milk and distribution issues. A members' liaison officer worked on weekly communication with the membership. Both LEADER ${ }^{2}$ and the Biodynamic Association of Ireland ${ }^{3}$ helped financially, through an educational grant and a loan, respectively. School educational courses were initiated with a local cookery school. (See figures 1 and 2 for the old and new CSA structures.)

At time of writing, spring 2014, these changes seem to have worked: the CSA is still operational. It is no bigger but no smaller either, remaining member-owned and -operated and retaining the same number of members, although personnel

\footnotetext{
2 LEADER stands for "Liaison Entre Actions de Développement de l'Économie Rurale," meaning "Links Between the Rural Economy and Development Actions." It is an EU initiative that gives financial assistance to implement local development strategies, by awarding grants to local projects. It is funded through Pillar 2 of the Common Agriculture Policy, the rural development pillar. See http://ec.europa.eu/agriculture/rur/leaderplus/ faq en.htm\#37 for more information.

3 The Biodynamic Association promotes the biodynamic agricultural impulse by emphasizing closed nutrient cycles through composting and saved seeds.
} 
Figure 1. Old CSA Structure



Figure 2. Revised CSA Structure

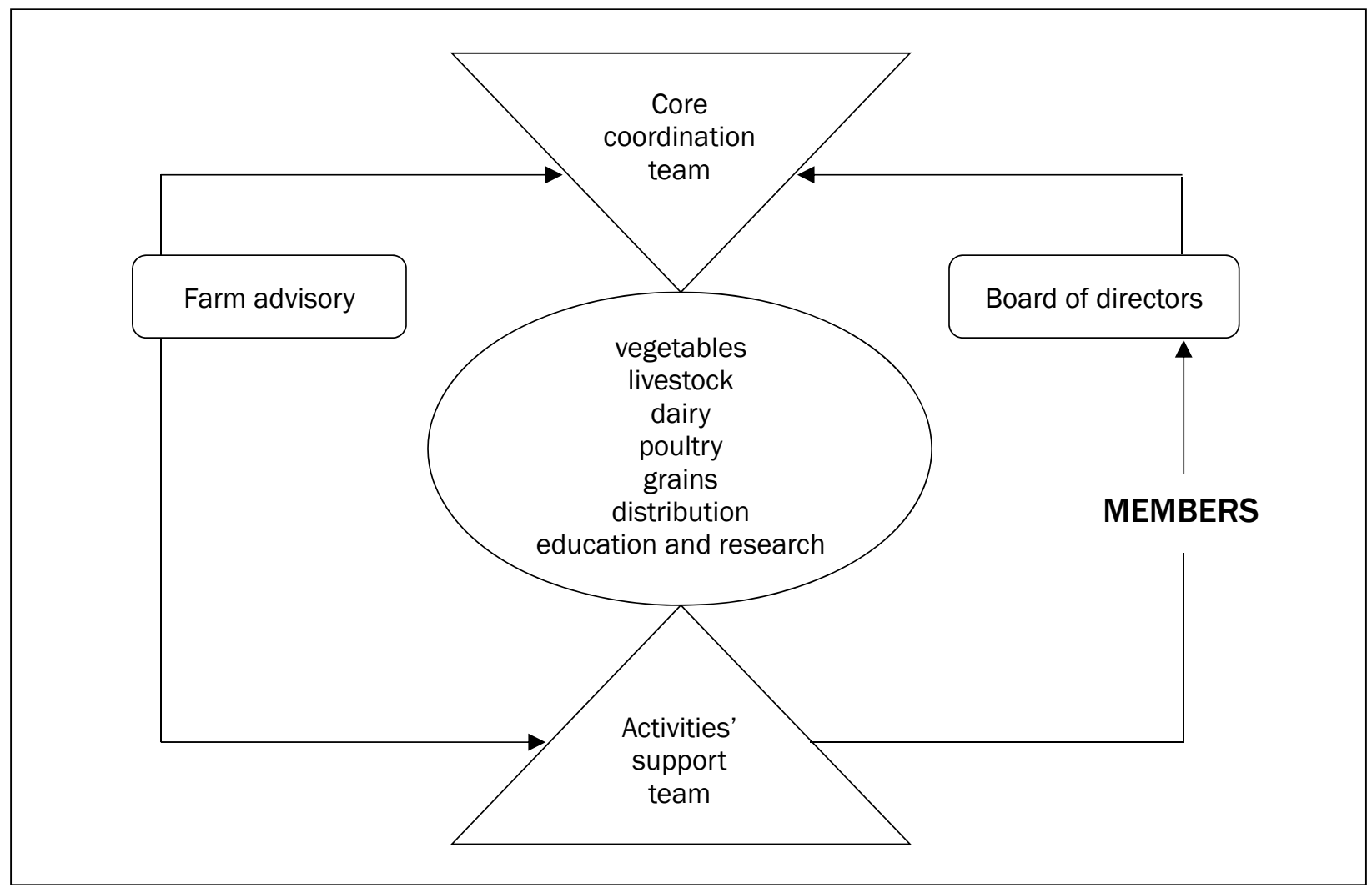


have changed somewhat. There have also been changes in production and distribution. Future papers will outline how this restructuring was built upon, as well as how the relationship with the intentional community has unfolded.

\section{Analysis}

How does this specific CSA tell us new things about civic food networks, in theory and practice? What role do equity, place, governance, and empowerment play? And what can the research community learn from what happened during that year with this CSA?

Equity was at the fore for this CSA, exemplified by the half-price produce for low-income households, unlocked doors, and "take what you need" ethos. While there is more to enabling the use of CSA produce by lower-income households than simply making it available and affordable, there are some examples of efforts in this regard too. Various learning initiatives, including participatory learning events, were held in local church halls, which helped people learn how to use surplus produce (gluts of seasonal vegetables or milk). Learning how to cope with gluts made the CSA a better value. Beyond economic equity, this CSA expressed an equity of participation in decisionmaking and activities. There are also inevitable limits to what can realistically be expected from a single CSA in equity terms, however.

Newcomers have played an important role in AAFNs and the organic movement in Ireland, as Tovey $(1997,2002)$ and Moore (2006b) point out. This location, or place, is also reflected in our study to an extent too. In place terms, the CSA was in an unusual geographical location: three religious communities and an intentional community in a small town is not typical of rural Ireland, which is predominantly Catholic. Some aspects of the produce reflected place in DeLind's (2011) terms, with fairly traditional vegetables, milk, and meat along with more novel produce (including, paradoxically, traditional/heirloom varieties) making up the weekly collection. That membership came from more than just the intentional community was a reflection of the wider place. Some of the CSA members were newcomers to the village who were attracted by the existence of an intentional commu- nity in the area, even though they did not reside in it. This is a reflection of place - of an evolving place - although local membership from outside the intentional community and associates was limited. However, taken as a whole, the presence of an intentional community makes place specifics for this CSA especially relevant. There were a range of other opportunities to interact with civic or alternative food networks - through allotments, a wholesale buyers' club, and a bread club. These other agri-food options, as well as the pioneering personnel involved in the CSA, mean that the distinctness of this place is certainly noteworthy.

The nature of governance mechanisms expressed by and through the CSA was certainly interesting, while having relevance for understanding place. The successful crowd-funding of loan stock could also be seen as a governance mechanism. Land-lease and subsequent biodynamic farming could be seen as part of the governance of rural spaces, akin to the AMAP behavior in France as outlined by Cardona \& Lamine (2011). The range of stakeholders enrolled through various processes, both internal and outreach, was used successfully to grow membership and stabilize the CSA. Moreover, internal and external networking linkages were developed and strengthened. The makeup of the stakeholders was also noteworthy: rural development supports (LEADER), the Biodynamic Association, local community, business and farming experts, and a blend of ecovillage, newcomer, local, and regional membership.

In terms of the balance between delegation and empowerment as referred to by DubuissonQuellier \& Lamine (2008), this member-owned and -operated CSA could be seen as closer to the empowerment than delegation end of the pendulum. Likewise, the range of volunteering, from partaking in events to some on-the-farm work such as harvesting and planting, exemplify empowerment. However, novel techniques of delegation were also apparent, which can be seen as empowered decisions, too. Having and housing WWOOFers represented delegation, as the hostel accommodation was rented at a financial cost to the CSA. Other supports offered to WWOOFers were an interesting blend of the two poles: delegating to "full time volunteers," while at the same 
time having to engage in various practices to facilitate WWOOFers, such as cooking or opening up a home for meals. Thus, even the delegation was dynamic, responsive, and engaged, while also being constructed to free up time. In part, this was because, with a majority of members also being intentional community members, there was always and inevitably something of a strain and drain on volunteering and empowerment, as the intentional community itself required significant levels of volunteering and help.

Importantly, however, the CSA was also under severe pressure from what are sometimes considered to be relatively under-important constraints. Dubuisson-Quellier \& Lamine's (2008) acceptable and unacceptable uncertainties consider external, bigger-picture factors like use of genetically modified seed or pesticide use as unacceptable, and constrained vegetable choice as acceptable. And in general, a core element of CSAs tends to be that risks and rewards are shared; the seasonality of vegetable production has to become a standard, normal part of the rhythm of the relationship. But what happens when the acceptable becomes unacceptable? In theory, acceptable risk is fine, but when participants end up with what they think of as not enough vegetables, in what they think should be a time of abundance, tensions inevitably rise. That the CSA came up with a new structure to adapt and cope is testimony to its robustness, or, specifically, its reflexive resilience.

Members themselves understood that there were risks and rewards: that they would have to support the farm even in the bad times. However, when the theoretical risk became the practical reality of not many vegetables, members adapted rather than carrying on without change or dropping away from the initiative. So they behaved in a reflexively resilient manner when faced with unexpected unacceptability. To elaborate, reflexive refers here to being critically self-aware and willing to change, and then managing to change. Resilience refers to being prepared for shocks, being always already adaptable and able to respond to the shocks if and when they occur. Taken together, the term reflexive resilience describes a CSA's robustness and its adaptive awareness. This notion of reflexive resilience describes both the act of looking and the act of being able to change.

The strength of its internal and external civic network, in particular through the 'barter' with the biodynamic community, was certainly a part of this: that the CSA had nothing specific to barter, except potential future produce, was an example of the shared risk and reward system operating on a larger, mesoscale rather than microscale. Being member-owned and -operated, this CSA was able to adapt and continue, however awkwardly and slowly, in a more genuinely civic manner. The governance mechanisms employed at the EGM are a good example of how this CSA reflected what are posited in this study as the especially important aspects of civic food networks: equity, participation, empowerment, and governance itself. The EGM's methodology could be seen as a microcosm of the civicness around food this CSA expresses: members sat around tables suggesting positives and negatives about the CSA, which were then placed on the wall. These were color-coded with stickers that each person placed beside the terms. The number and color of stickers pointed to the importance of the issue. EGM decision-making was thus not board-driven or top-down; instead, decisions came from and through the membership.

But this CSA reflects more than these aspects of civicness we demark as important - equity, place, governance, and empowerment. Its robustness, adaptability, and always-already readiness to critically self-assess and change were noteworthy, and are what we are terming here to be reflexive resilience. To emphasize, all these factors, taken together, form the matrix of reflexive resilience: the ability to critically self-assess and adapt to circumstance; a participatory process to develop emergent organizational structures; member-owned and -operated functionality; methods of expressing equity, place, and governance; engagement techniques and adaptability with regard to navigating the balance between enrollment and delegation as well as between acceptable and unacceptable uncertainties.

\section{Conclusion}

Moore (2006b, 2006c, 2008) and Briscoe et al. (2010) point to the local benefits of what are termed participatory farmers' markets (and, 
although not to the same extent, pioneering or privately run farmers' markets) due to the range of stakeholders they enroll. This CSA also enrolls participation, thus showing parallels between AAFNs and civic food networks in the Irish situation. To reiterate, governance mechanisms, empowerment, and equity, along with participation, have been shown to be important in the functioning of this CSA. The level and style of engagement these four elements involve make them especially civic acts. With this as a civic foundation, another dynamic emerged, building upon this civic base. Finding that constrained vegetable choice, unexpectedly, became an unacceptable uncertainty was a core motivation in this CSA expressing what we are terming here reflexive resilience: robust and critical self-awareness, along with a willingness and ability to change to adapt in the face of challenges.

So what can the research community learn from this, and what is missing from our analysis thus far? In both cases, the answer is a lot, but with limits. Campbell, Carlisle-Cummins and Feenstra (2013) note it is important to attempt to bridge the gap between research and practice in community food systems. The learning outcomes from this study emerged from the lived experience of being a CSA member in a particular place for a year, so the study was practice-led. Moreover, this research, in the style of backyard ethnography (Heley, 2011), gives extremely deep access to very rich, very embedded sources of insider data. So this research, following Fuller (1999), was not so much about 'going native' as about being aware of the issues and benefits of being as 'native' as any other newcomer in a CSA established by a community of newcomers. As Campbell et al.(2013)stated, "practitioners need to be active partners in advancing and generating new knowledge. This might include putting greater priority on fostering partnerships between practitioners and researchers to design and implement research projects on identified challenges"(p. 133).

Beyond the methodological, learning can ensue from how a member-owned and -operated CSA acted in an especially civic and also reflexively resilient way. Thus the techniques and methods from this CSA's functioning and restructuring have generated theoretically useful notions. Both communities and researchers can potentially learn from these practices and their theoretical meaning.

While there are benefits to this very immersive and very specific study, there are also noteworthy limitations. Developing any theories from a study of just one CSA, and one that emerged from an intentional community at that, demands caution. Intentional communities are rare in general, and in Ireland the intentional community in question is the only one. Granted, major cities may have scattered around them similar populations of people interested in the kinds of issues people in this particular place are interested in, as Dublin had before these people moved to the intentional community, for example. Nevertheless, this place has undeniable uniqueness: strong internal and external networks and an especially participatory functionality and structure. Whether, and if so how, the organizational structure of the CSA relates recursively to the intentional community's organizational structure will thus be a topic of future research.

This possible limitation, or certainly defining characteristic, warrants a dedicated study. Place and organizational transitioning, or community capitals (e.g., Brunori et al., 2010; Cardona \& Lamine, 2011; and Emery \& Flora, 2006) may prove to be fruitful in better understanding how this CSA has functioned in the intervening years. That it is still functioning, without growing dramatically, is noteworthy.

Likewise, the CSA's operational organizational structure is worthy of further exploration. Better understanding why there are still so few CSAs in Ireland is another area of consideration. Is it because AAFNs are in some regards quite strong in Ireland? Or is it the effects of the economic recession? Certainly the study of this CSA offers up many opportunities for learning: potentially the model and the ethnographic method of study could be replicated elsewhere.

\section{References}

Balázs, B. (2012). Local food system development in Hungary. International Journal of Sociology of Agriculture and Food, 19(3), 403-421. http://ijsaf.org/

Bord Bia. (2013). Irish companies exhibit at World Organic Trade Fair [Press release]. Retrieved from http://www.bordbia.ie/corporate/press/2013/pag es/BioFach2013.aspx 
Briscoe, R., McCarthy, O., Moroney, A., O’Shaughnessy, M., \& Ward, M. (2010). Effective structures for farmers' markets in Ireland. Report to the Department of Agriculture, Fisheries and Food. Summary report available at http://www.agriculture.gov.ie/media/ migration/research/rsfallfundedprojects/2006 projects/RSF06323.pdf

Brunori, G., Rossi, A., \& Malandrin, V. (2010). Coproducing transition: Innovation processes in farms adhering to solidarity-based purchase groups (GAS) in Tuscany, Italy. International Journal of Sociology of Agriculture and Food, 18(1), 28-53.

http://ijsaf.org/index.html

Campbell, D. C., Carlisle-Cummins, I., \& Feenstra, G. (2013). Community food systems: Strengthening the research-to-practice continuum. Journal of Agriculture, Food Systems, and Community Development, 3(3), 121-138. http://dx.doi.org/10.5304/jafscd.2013.033.008

Cardona, A., \& Lamine, C. (2011). Emergence of new forms of collective action and governance through alternative food networks: The case of an "AMAP" in France. Paper presented at the $24^{\text {th }}$ European Society for Rural Sociology (ESRS) Congress, Chania, Greece. Retrieved from http://prodinra.inra.fr/record/226435

Crotty, R. D. (1965). Irish agricultural production: Its volume and structure. Cork: Cork University Press.

Dahlberg, K. A. (1993). Regenerative food systems: Broadening the scope and agenda of sustainability. In P. Allen (Ed.), Food for the Future: Conditions and Contradictions of Sustainability (pp. 75-102). New York: Wiley.

DeLind, L. B. (1999). Close encounters with a CSA: The reflections of a bruised and somewhat wiser anthropologist. Agriculture and Human V alues, 16(1), 3-9. http://dx.doi.org/10.1023/A:1007575521309

DeLind, L. B. (2002). Place, work, and civic agriculture: Common fields for cultivation. Agriculture and Human Values, 19(3), 217-224. http://dx.doi.org/10.1023/A:1019994728252

DeLind, L. B. (2011). Are local food and the local food movement taking us where we want to go? Or are we hitching our wagons to the wrong stars? Agriculture and Human V alues, 28(2), 273-283. http://dx.doi.org/10.1007/s10460-010-9263-0
Department of Agriculture, Fisheries and Food. (2010). Food harvest 2020: A vision for Irish agri-food and fisheries. Retrieved from https://www.agriculture. gov.ie/agri-foodindustry/foodharvest $2020 /$

Dubuisson-Quellier, S., \& Lamine, C. (2008). Consumer involvement in fair trade and local food systems: Delegation and empowerment regimes. GeoJournal, 73(1), 55-65. http://dx.doi.org/10.1007/s10708008-9178-0

Emery, M., \& Flora, C. (2006). Spiraling-up: Mapping community transformation with Community Capitals Framework. Community Development, 37(1), 19-35. http://dx.doi.org/10.1080/15575330609490152

Flora, C. B., \& Bregendahl, C. (2012). Collaborative community-supported agriculture: Balancing community capitals for producers and consumers. International Journal of Sociology of Agriculture and Food, 19(3) 329-346. http://www.ijsaf.org/index.html

Fonte, M., Pinto, B., Eboli, M., Ornella, M., \& Salvioni, C. (2011). The five dimensions of sustainability: The experience of solidarity purchasing groups in Rome, Italy. Paper presented at the $14^{\text {th }}$ European Society for Rural Sociology (ESRS) Congress, Chania, Greece.

Fuller, D. (1999). Part of the action, or 'going native'? Learning to cope with the 'politics of integration.' Area, 31(3), 221-227. http://dx.doi.org/10.1111/ j.1475-4762.1999.tb00086.x

Goodman, D. (2004). Rural Europe redux? Reflections on alternative agro-food networks and paradigm change. Sociologia Ruralis, 44(1), 3-16. http://dx.doi.org/10.1111/j.14679523.2004.00258.x

Heley, J. (2011). On the potential of being a village boy: An argument for local rural ethnography. Sociologia Ruralis, 51(3), 219-237. http://dx.doi.org/ 10.1111/i.1467-9523.2011.00534.x

Holloway, L., Kneafsey, M., Venn, L., Cox, R., Dowler, E., \& Tuomainen, H. (2007). Possible food economies: A methodological framework for exploring food production-consumption relationships. Sociologia Ruralis, 47(1), 1-19. http://dx.doi.org/10.1111/j.14679523.2007.00427.x 
Karner, S. (Ed.). (2010). Local food systems in Europe: Case studies from five countries and what they imply for policy and practice[Facilitating Alternative Agro-food Networks (FAAN) report]. Graz, Austria: IFZ. Retrieved from http://www.faanweb.eu/sites/faanweb.eu/ files/FAAN Booklet PRINT.pdf

Kirwan, J. (2004). Alternative strategies in the UK agrofood system: Interrogating the alterity of farmers' market. Sociologia Ruralis, 44(4), 395-415. http://dx.doi.org/10.1111/j.14679523.2004.00283.x

Lamine, C. (2005). Settling shared uncertainties: Local partnerships between producers and consumers. Sociologia Ruralis, 45(4), 324-345. http://dx.doi.org/ 10.1111/j.1467-9523.2005.00308.x

Lyson, T. A. (2000). Moving toward civic agriculture. Choices: The Magazine of Food, Farm \& Resource Issues, 15(3), 42-45. http://ageconsearch.umn.edu/

Marsden, T. (2000). Food matters and the matter of food: Towards a new food governance? Sociologia Ruralis, 40(1), 20-29. http://dx.doi.org/10.1111/1467-9523.00129

Moore, O. (2006a). Farmers' markets. In M. P. Corcoran, and M. Peillon (Eds.), Uncertain Ireland: A Sociological Chronicle, 2003-2004 (pp. 129-140). Dublin: Institute of Public Administration.

Moore, O. (2006b). What farmers' markets say about the post-organic movement in Ireland. In G. C. Holt \& M. Reed (Eds.), Sociological Perspectives of Organic Agriculture (pp. 18-36). Oxford: CABI. http://dx.doi.org/10.1079/9781845930387.0018

Moore, O. (2006c). Understanding postorganic fresh fruit and vegetable consumers at participatory farmers' markets in Ireland: Reflexivity, trust and social movements. International Journal of Consumer Studies, 30(5), 416-426. http://dx.doi.org/ 10.1111/j.1470-6431.2006.00537.x

Moore, O. (2008). How embedded are organic fresh fruits and vegetables at Irish farmers' markets and what does the answer say about the organic movement? An exploration, using three models. International Journal of Agricultural Resources, Governance and Ecology, 7(1/2), 144-157. http://dx.doi.org/10.1504/IJARGE.2008.016985

Murdoch, J., Marsden, T., \& Banks, J. (2000). Quality, nature, and embeddedness: Some theoretical considerations in the context of the food sector.
Economic Geography, 76(2), 107-125. http://dx.doi.org/10.2307/144549

Murdoch, J., \& Miele, M. (2004). A new aesthetic of food? Relational reflexivity in the 'alternative' food movement. In M. Harvey, A. McMeekin \& A. Warde (Eds.), Qualities of Food: Alternative Theoretical and Empirical Approaches (pp. 156-175). Manchester: Manchester University Press.

Ravenscroft, N., \& Taylor, B. (2009). Public engagement in new productivism. In M. Winter \& M. Lobley (Eds.), What is Land For? The Food, Fuel and Climate Change Debate (pp. 213-232). London: Earthscan.

Renting, H., Schermer M., \& Rossi, A. (2012). Building food democracy: Exploring civic food networks and newly emerging forms of food citizenship. International Journal of Sociology of Agriculture and Food, 19(3) 289-307. http://www.ijsaf.org/index.html

Sage, C. (2003). Social embeddedness and relations of regard: Alternative 'good food' networks in southwest Ireland. Journal of Rural Studies, 19(1), 47-60. http://dx.doi.org/10.1016/S0743-0167(02)00044X

Saltmarsh, N., Meldrum, J., \& Longhurst, N. (2011). The impact of community supported agriculture[Final report].

Bristol, UK: Soil Association CSA Support Project. Retrieved from http://www.soilassociation.org/LinkClick.aspx?file ticket $=$ DnZ0pAZbjzM\%3d\&tabid $=204$

Smith, E., \& Marsden, T. (2004). Exploring the limits to growth' in UK organics: Beyond the statistical image. Journal of Rural Studies, 20(3), 345-357. http://dx.doi.org/10.1016/S0743-0167(03)00044-5

Soil Association. (2010). Community supported agriculture: A teaching programme for degree students in agriculture and related subjects.

Retrieved October 12, 2013, from http://www.soilassociation.org/communitysupport edagriculture/resources/research

Thompson, C. J., \& Coskuner-Balli, G. (2007). Enchanting ethical consumerism: The case of Community Supported Agriculture. Journal of Consumer Culture, 7(3), 275-303. http://dx.doi.org/10.1177/1469540507081631

Tovey, H. (1982). Milking the farmer? Modernisation and marginalisation in Irish dairy farming. In $\mathrm{M}$. Kelly, L. O’Dowd, \& J. Wickham (Eds.), Power, Conflict and Inequality (pp. 68-89). Dublin: Turoe Press/Marion Boyars. 
Tovey, H. (1997). Food, environmentalism and rural sociology: On the organic farming movement in Ireland. Sociologia Ruralis, 37(1) 21-37. http://dx.doi.org/10.1111/1467-9523.00034

Tovey, H. (2001). The co-operative movement in Ireland: Reconstructing civil society. In H. Tovey \& M. Blanc (Eds.), Food, Nature and Society: Rural Life in Late Modernity (pp. 321-338). Aldershot, UK: Ashgate.

Tovey, H. (2002). Alternative agriculture movements and rural development cosmologies. International
Journal of Sociology of Agriculture and Food, 10(1) 1-11. http://www.ijsaf.org/index.html

Van der Ploeg, J. D., \& Renting, H. (2004). Behind the 'redux': A rejoinder to David Goodman. Sociologia Ruralis, 44(2), 234-242. http://dx.doi.org/ 10.1111/j.1467-9523.2004.00272.x

Vitek, W. (1996). Community and the virtue of necessity. In W. Vitek \& W. Jackson (Eds.), Rooted in the Land: Essays on Community and Place (pp. 176184). New Haven, Connecticut: Yale University Press. 